\title{
SWAN MRI revealing multiple microhemorrhages secondary to septic emboli from mucormycosis
}

Figure $1 \quad$ Brain MRI
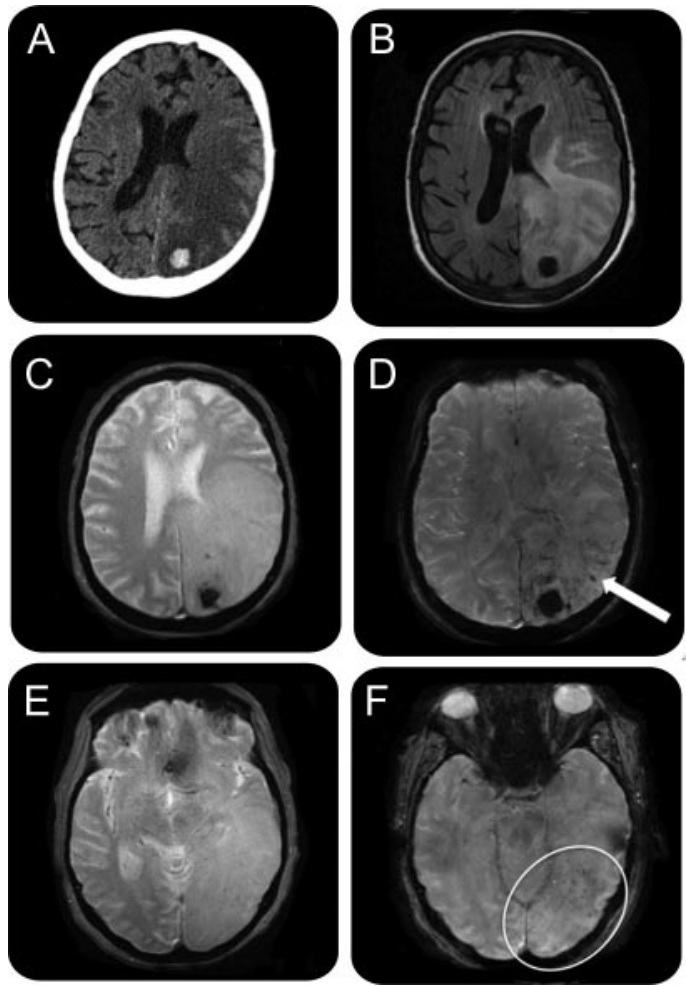

(A) CT: left parietal-occipital hemorrhage with surrounding edema. (B) Fluid-attenuated inversion recovery MRI. (C, E) T2-gradient recall echo (GRE) suggestive of hemorrhage and 1 microhemorrhage. (D, F) T2 star-weighted angiography reveals many microhemorrhages (punctate black regions within white circle), likely secondary to septic emboli. White arrow corresponds to arrow in figure 2A.

A 77-year-old man with myelodysplastic syndrome presented with fever and acute renal failure, followed by right-sided hemiparesis, neglect, and aphasia. Neuroimaging revealed a left parietal-occipital ICH with extensive edema. T2-star susceptibility weighted angiography (SWAN) revealed multiple microhemorrhages within the swollen hemisphere (figure 1). Autopsy findings included perivesical/peripelvic abscesses (Rhizopus species) and pulmonary septic thromboembolus. Neurologic deficits resulted from septic emboli/microemboli of this angioinvasive fungus causing focal encephalitis, ruptured mycotic aneurysm, and multiple microhemorrhages (figure 2). Infection from the order Mucorales constitutes mucormycosis.

SWAN imaging delineates microhemorrhages better than conventional MRI (T2 gradient recall echo). Microhemorrhages occur in chronic hypertension, cerebral amyloid angiopathy, septic emboli, cerebral autosomal dominant arteriopathy with subcortical infarcts and leukoencephalopathy, familial CNS cavernous malformations, and other rare conditions. ${ }^{1}$

\section{Michele A. Scully, MD, Gabrielle A. Yeaney, MD, Margaret L. Compton, Michel J. Berg, MD, Rochester, NY}

M. Scully, G. Yeaney, and M. Compton report no disclosures relevant to the manuscript. M. Berg is the Principal Investigator for studies sponsored by the FDA, Site Principal Investigator for studies sponsored by Neuropace, and Site Subinvestigator for studies sponsored by Pfizer, Sunovion Pharmaceuticals, Eisai, UCB Pharma, Lundbeck LLC, and Supernus Pharmaceuticals. Go to Neurology.org for full disclosures.

Correspondence \& reprint requests to Dr. Scully: Michele_Scully@urmc.rochester.edu 
Figure 2 Gross pathology and histologic sections

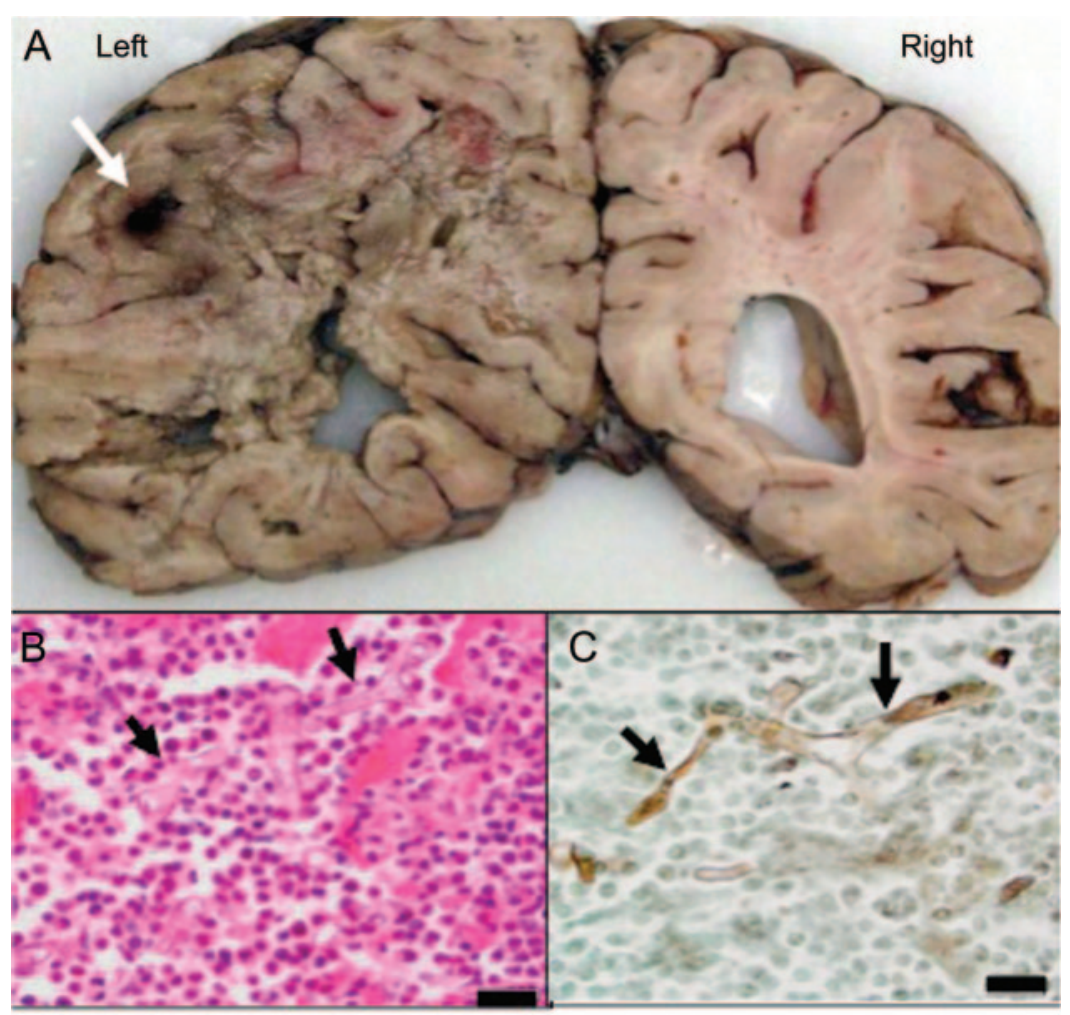

(A) Coronal section of left parietal cortex reveals hemorrhage (white arrow) with surrounding necrosis and edema. (B, C) Microscopic sections show neutrophilic infiltrate and aseptate branching fungal hyphae (black arrows) on hematoxylin \& eosin and Gomori methenamine silver stains (black marker $=20 \mu \mathrm{m}$ ).

1. Blitsein MK, Tung GA. MRI of cerebral microhemorrhages. AJR Am J Roentgenol 2007;189:720-727. 


\section{Neurology}

\section{SWAN MRI revealing multiple microhemorrhages secondary to septic emboli from mucormycosis}

Michele A. Scully, Gabrielle A. Yeaney, Margaret L. Compton, et al. Neurology 2012;79;1932-1933

DOI 10.1212/WNL.0b013e318271f86c

This information is current as of October 29, 2012

\section{Updated Information \& Services}

References

Citations

Subspecialty Collections

Permissions \& Licensing

Reprints including high resolution figures, can be found at: http://n.neurology.org/content/79/18/1932.full

This article cites 1 articles, 0 of which you can access for free at: http://n.neurology.org/content/79/18/1932.full\#ref-list-1

This article has been cited by 1 HighWire-hosted articles: http://n.neurology.org/content/79/18/1932.full\#\#otherarticles

This article, along with others on similar topics, appears in the following collection(s):

\section{Embolism}

http://n.neurology.org/cgi/collection/embolism

Encephalitis

http://n.neurology.org/cgi/collection/encephalitis

Fungal infections

http://n.neurology.org/cgi/collection/fungal_infections

Intracerebral hemorrhage

http://n.neurology.org/cgi/collection/intracerebral_hemorrhage

MRI

http://n.neurology.org/cgi/collection/mri

Information about reproducing this article in parts (figures,tables) or in its entirety can be found online at:

http://www.neurology.org/about/about_the_journal\#permissions

Information about ordering reprints can be found online:

http://n.neurology.org/subscribers/advertise

Neurology ${ }^{\circledR}$ is the official journal of the American Academy of Neurology. Published continuously since 1951, it is now a weekly with 48 issues per year. Copyright Copyright $@ 2012$ by AAN Enterprises, Inc.. All rights reserved. Print ISSN: 0028-3878. Online ISSN: 1526-632X.

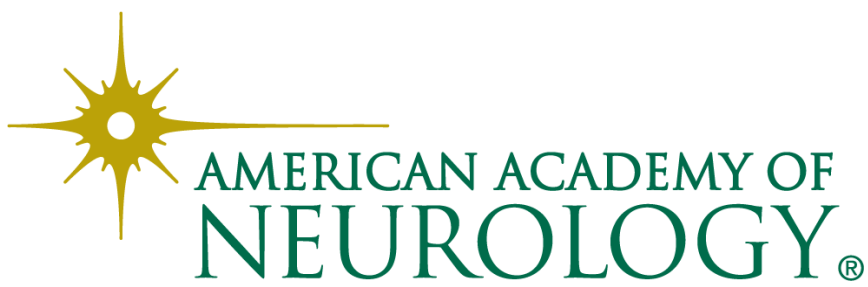

